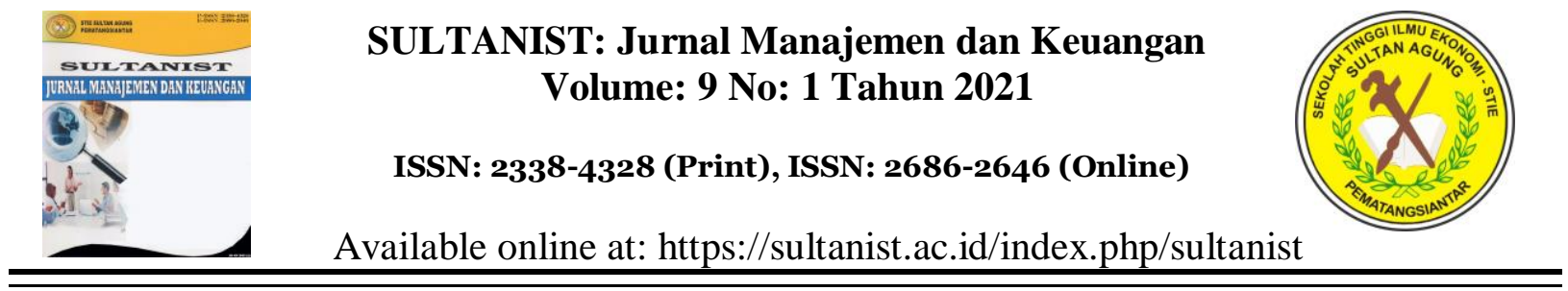

\title{
PENGARUH IKLIM KERJA DAN MOTIVASI TERHADAP KINERJA UKM BINAAN BANK SUMUT CABANG KAMPUNG BARU MEDAN
}

\author{
Yohny Anwar ${ }^{1)}$ \\ ${ }^{1}$ Master of Management Program, Universitas Pembangunan Panca Budi Medan, Indonesia \\ ${ }^{2}$ Program Studi Manajemen, Sekolah Tinggi Ilmu Ekonomi Sultan Agung, Pematangsiantar, Indonesia \\ *E-mail: yohny.anwar@yahoo.com
}

\begin{abstract}
Abstrak
Penelitian ini bertujuan untuk mengetahui dan mengananlisis kinerja Aparatur Pada Badan Pengelolaan Keuangan Pendapatan dan Aset Daerah (BPKPAD) Kota Binjai yang terdiri dari insentif, disiplin,prestise terhadap kinerja Metode analisis data yang digunakan dalam penelitian ini menggunakan analisis regresi berganda (Multiple Regression Analysis) dengan melakukan uji kualitas data, uji asumsi klasik, uji hipotesis dan koefisisen determinasi dengan menggunakan program Statistical Package for Social Science (SPSS). Populasi dalam penelitian ini adalah seluruh pegawai yang berstatus PNS pada Badan Pengelolaan Keuangan, Pendapatan dan Aset Daerah (BPKPAD) Kota Binjai yang berjumlah 93 orang pegawai. Seluruh populasi digunakan sebagai sampel. Hasil penelitian ini membuktikan bahwa Secara parsial variabel disiplin, insentif, dan prestise berpengaruh positif dan signifikan terhadap kinerja aparatur pada Badan Pengelolaan Keuangan Pendapatan dan Aset Daerah Kota Binjai. Disiplin merupakan variabel dominan dalam mempengaruhi kinerja aparatur pada Badan Pengelolaan Keuangan Pendapatan dan Aset Daerah Kota Binjai. Disiplin, insentif, dan prestise secara simultan berpengaruh positif signifikan terhadap kinerja aparatur pada Badan Pengelolaan Keuangan Pendapatan dan Aset Daerah Kota Binjai.
\end{abstract}

Kata kunci: Iklim Kerja , Motivasi, Kinerja

\section{THE EFFECT OF WORK CLIMATE AND MOTIVATION ON THE PERFORMANCE OF BANK SUMUT SMES, KAMPUNG BARU MEDAN BRANCH}

\begin{abstract}
This study aims to determine and analyze the performance of the Apparatus at the Regional Income and Asset Financial Management Agency (BPKPAD) of Binjai City which consists of incentives, discipline, prestige for performance.The data analysis method used in this study uses multiple regression analysis with multiple regression analysis. perform data quality test, classic assumption test, hypothesis test and coefficient of determination using the Statistical Package for Social Science (SPSS) program. The population in this study were all employees with civil servant status at the Binjai City Financial, Revenue and Asset Management Agency (BPKPAD) totaling 93 employees. The entire population is used as the sample. The results of this study prove that partially the variables of discipline, incentives, and prestige have a positive and significant effect on the performance of officials at the Regional Income and Asset Financial Management Agency of Binjai City. Discipline is the dominant variable in influencing the performance of officials at the Binjai City Regional Income and Asset Financial Management Agency. Discipline, incentives, and prestige simultaneously have a significant positive effect on apparatus performance at the Binjai City Regional Income and Asset Financial Management Agency. Keywords: Emotional Intelligence, Self-Efficacy, OCB, Employee Performance.
\end{abstract}

Keywords: Work Climate, Motivation, Performance

Article History: Received: 21 Mei $2021 \quad$ Revised: 23 Mei $2021 \quad$ Accepted: 29 Mei 2021 


\section{SULTANIST: Jurnal Manajemen dan Keuangan, Vol 9 (1), Juni 2021}

\section{PENDAHULUAN}

Usaha Kecil dan Menengah (UKM) umumnya memiliki keunggulan dalam bidang yang memanfaatkan sumberdaya alam dan padat karya, misalnya pertanian tanaman pangan, perkebunan, peternakan, perikanan, perdagangan dan restoran. Suasana atau kondisi di tempat kerja harus di desain senyaman mungkin untuk karyawan. Karena hal ini akan berpengaruh pada kinerjanya diberikan (Lie et al., 2021). Semua organisasi akan memiliki iklim kerja yang berbeda, yang akan disesuaikan dengan strategi dalam manajemen sumber daya manusia perusahaan, pekerja/karyawan sebagai SDM memerlukan komunikasi terbuka dalam batas-batas wewenang dan tanggungjawab masing-masing (Sahir et al., 2020)

Komunikasi yang lancar untuk memperoleh informasi-informasi yang dipandang penting oleh pekerja/karyawan dan disampaikan tepat waktunya,dapat menimbulkan rasa puas dan menciptakan motivasi kerja positif (Pakpahan et al., 2019). manajemen sumber daya manusia sangat memperhatikan proses pekerjaan kinerja karyawan sesuai dengan beban kerja yang ada dalam organisasi dengan menciptakan suasana lingkungan yang harmonis, dimana hubungan pimpinan perusahaan dengan kinerja karyawan dan hubungan antar devisi/bagian dalam suatu organisasi akan memberi dampak yang sehat dan nyaman diantara sesama karyawan (Ayesha et al., 2021), karena karyawan merupakan salah satu modal penting (Human Capital ) bagi perusahaan.

Seorang manajer yang baik adalah orang yang memiliki needs for Power yang kuat, seorang manajer harus mengelola kinerja orang lain (Candra et al., 2019). Seorang wirausahawan harus memonitor baik keberhasilan maupun kegagalan dalam melakukan penjualan, mengambil tanggung jawab untuk melakukan telepon kepada calon klien, mengambil resiko yang terkalkulasi, harus mengambil keputusan mengenai prospek yang harus ditindaklanjuti, dan menemukan cara yang inovatif untuk membujuk orang agar membeli produk atau jasanya. Selain itu usaha mikro dan kecil ini diharapkan berkembang menjadi usahaskala menengah dan besar.

Mengembangkan kinerja UKM bukan hal yang mudah. Barbara (2000) mengatakan bahwa permasalahan bidangmanajemen dalam pemasaran, keuangan, teknologi sangat berpengaruh terhadap pengembangan kinerja UKM. Kelemahan ini dibuktikan dari hasil penelitian BI Cabang Medan bekerja sama dengan Universitas Sumatera Utara (USU) pada Oktober 2008 diketahui hanya 22,5\% pelaku UKM yang memiliki laporan keuangan dan $87,8 \%$ pelaku UKM yang menyusun laporan keuangan secara tidak layak. Hal ini disebabkan karena rendahnya pendidikan dan kurangnya pemahaman terhadap Standar Akuntansi Keuangan serta tidak adanya peraturan yang mewajibkan penyusunan laporan keuangan bagi UKM dan pelaku UKM masih merangkap tugas dalam menjalankan usahanya di bidang pemasaran, kegiatan operasi, mengatur SDM dan keuangan serta transaksi juga masih sederhana. Iklim pada organisasi mempengaruhi 4 (empat) prinsip seperti a. Manajer/pimpinan. b. Tingkah laku karyawan. c. Tingkah laku kelompok kerja dan d. Tingkah laku kelompok kerja. Seandainya pemerintah telah menetapkan 


\section{SULTANIST: Jurnal Manajemen dan Keuangan, Vol 9 (1), Juni 2021}

aturan tentang pemberian upah dan harga yang dapat membatasi peningkatan keuntungan, karyawan mungkin menjadi tidak senang dan bisa keluar untuk mendapatkan pekerjaan pada perusahaan lain. Di lain pihak, ledakan ekonomi dapat mendorong penjualan dan memungkinkan setiap orang mendapatkan pekerjaan dan peningkatan keuntungan yang besar, sehingga hasilnya iklim menjadi lebih positif.Bank Sumut adalah sebuah bank daerah yang ikut andil dalam pengembangan usaha mikro dan kecil di wilayah Sumatera Utara, lewat pengucuran kredit usaha mikro dan kecil yang lebih dikenal dengan Sumut Sejahtera 1 dan 2 (SS1 dan SS2), yang dalam realisasinya banyak menemukan kendala yang berasal dari usaha binaan itu sendiri yang menyebabkan tujuan dari pemberian kredit ini tidak dirasakan secara maksimal oleh usaha mikro tersebut.

Bank Sumut melakukan kegiatan pembinaan terhadap usaha mikro yang tergolong dalam kelompok binaan SS1 dan SS2, mengingat karena loyalitas dari pengusaha mikro terhadap Bank Sumut sangat tinggi, sehingga dapat terjalin hubungan jangka panjang dengan pihak Bank lewat promosi yang dilakukan dari mulut ke mulut yang disampaikan dilingkungan keluarga pengusaha mikro, mengajak keluarga untuk menjadi nasabah Bank Sumut. Disamping itu banyak kendala yang dihadapi Bank Sumut dalam melakukan kegiatan pengembangan usaha mikro ini, antara lain sulitnya menerapkan program pembinaan mengingat tingkat pendidikan pengusaha mikro yang rendah dan bahkan banyak yang buta huruf, disamping kendala lain yang berasal dari Bank Sumut itu sendiri, karena Bank Sumut dalam kegiatan pengembangan usaha mikro mewakilkan kepada Account Officer (AO) dari Bank Sumut untuk membentuk kelompok usaha, dan tidak semua AO memiliki kemampuan yang memadai untuk melakukan kegiatan pengembangan usaha mikro.Berdasarkan latar belakang yang diuraikan diatas peneliti tertarik untuk melakukan penelitian dengan judul Pengaruh iklimkerja dan motivasi terhadap kinerja UKM Binaan Bank Sumut Cabang Kampung Baru Medan.

\section{LANDASAN TEORI}

\section{Iklim Kerja}

Iklim kerja adalah nilai semangat yang mendasar pada cara mengelola hubungan dan mengorganisasikannya. Nilai-nilai itu berbentuk prinsip dan keyakinan yang dapat tersurat, namun juga ada yang tersirat. Nilai-nilai ini mempengaruhi individu dalam melakukan tugas organisasi. Robbins (2007:716) menyatakan bahwa iklim kerja adalah istilah yang dipakai untuk memuat rangkaian variabel perilaku yang mengacu pada nilai-nilai, kepercayaan dan prinsip pokok yang berperan sebagai suatu dasar bagi sistem organisasi. Sedangkan menurut Davis dan Newstrom (2001:25), iklim kerja adalah kepribadian sebuah organisasi yang membedakan dengan organisasi lainnya yang mengarah pada persepsi masingmasing anggota dalam memandang organisasi.Semua organisasi memiliki iklim kerja yang manusiawi dan partisipatif, sesuai dengan gaya kepemimpinan. Iklim kerja dapat dipengaruhi oleh motivasi,prestasi dan kepuasan kerja.Iklim kerja dapat di golongkan menjadi 6 (enam) kondisi : iklim terbuka, iklim bebas, iklim terkontrol, iklim familier (kekeluargaan), iklim parternal, iklim tertutup.

Selain itu iklim kerja yang kondusif mendorong semua personil yang terlibatdalam organisasi untuk bertindak dan melakukan yang terbaik yang mengarah pada prestasi kerja yang tinggi. Perubahan 


\section{SULTANIST: Jurnal Manajemen dan Keuangan, Vol 9 (1), Juni 2021}

yang terjadi baik yang terjadi di dalam (internal) ataupun di luar (eksternal) organisasi akan sangat berpengaruh terhadap iklim kerja organisasi tersebut. Sebagai sebuah entitas yang penting di dalam sebuah organisasi, setiap individu tentunya mengharapkan mampu bekerja di suatu iklim yang kondusif. Iklim yang kondusif akan menciptakan sebuah kondisi yang mendorongnya untuk bekerja dengan giat. Steers dan Porter (1991, dalam Sumantri, 2001) mengemukakan faktor-faktor yang mempengaruhi iklim kerja:

1.Struktur Organisasi

Struktur organisasi merupakan sesuatu hal yang membuat hubungan yang tetap antara individu dengan organisasi sehingga sangat menentukan pola-pola interaksi, hubungan antar karyawan yang terkoordinir serta tingkah laku yang berorientasi pada tugas struktur.

2.Kebijakan dan Praktik Manajerial

Kebijakan dan praktik manajerial menjadi alat bagi pimpinan untuk memberikan arahan kepada setiap karyawan pada setiap kegiatan yang digunakan untuk pencapaian tujuan organisasi.

3.Teknologi

Teknologi memberikan manfaat berdasarkan pada pengetahuan dan peralatan serta diterapkan dalam pelaksanaan tugas.Hasil penelitian Burns dan Stalker menyatakan teknologi dan suasana memiliki hubungan yang negatif dalam penciptaan iklim kerja apabila dilaksanakan secara rutin sehingga kepercayaan dan kreativitas menjadi rendah. 4.Lingkungan Eksternal

Lingkungan eksternal umumnya menjadi penggambaran terhadap kekuatan-kekuatan yang berada di luarorganisiasi serta dapat mempengaruhi tujuan organisasi itu sendiri.

\section{Motivasi}

Menurut Robbins dan Judge (2008) mendefinisikan motivasi sebagai proses yang menjelaskan intensitas, arah dan ketekunan usaha untuk mencapai suatu tujuan. Vroom (1964) dalam Luthans (2006) mengatakan kekuatan motivasi adalah valensi dan harapan. Teori pengharapan berargumentasi bahwa motivasi kerja ditentukan oleh keyakinan individu yang berhubungan dengan, hubungan usahakinerja (expectancy = pengharapan), hubungan kerja-hasil (instrumental = perantara),dan persepsi pentingnya berbagai macam hasil pekerjaan (valence $=$ valensi) .

Teori Motivasi

Teori motivasi dapat dikategorikan dalam 3 kelompok yang dikemukakan oleh Mangkunegara (2009:63), 3 kelompok tersebut adalah :

a. Teori motivasi dengan pendekatan isi (content theory).

Teori ini lebih menekankan pada faktor apa yang membuat pegawai melakukan suatu tindakan/kegiatan.

b. Teori motivasi dengan pendekatan proses (process theory)

Teori ini tidak hanya menekankan pada faktor yang membuat pegawai melakukan suatu tindakan, akan tetapi teori ini juga lebih menekankan pada proses bagaimana pegawai termotivasi.

c. Teori motivasi dengan pendekatan penguat (reinforcemet theory).

Teori ini lebih menekankan pada faktor yang dapat meningkatkan suatu tindakan dilakukan atau yang dapat mengurangi suatu tindakan dilakukan.

Ada beberapa teori motivasi yang dikemukakan oleh ilmuwan yang menekuni kegiatan pengembangan teori motivasi.

Prinsip-Prinsip Motivasi

Terdapat beberapa prinsip dalam memotivasi kerja karyawan menurut Mangkunegara (2009:61) diantaranya yaitu

Prinsip partisipasi

Dalam upaya memotivasi kerja, pegawai perlu diberikan kesempatan ikut berpatisipasi dalam menentukan tujuan yang akan dicapai oleh pemimpin Prinsip komunikasi 


\section{SULTANIST: Jurnal Manajemen dan Keuangan, Vol 9 (1), Juni 2021}

Pemimpin mengkomunikasikan segala sesuatu yang berhubungan dengan usaha pencapaian tugas, dengan informasi yang jelas, pegawai akan lebih mudah dimotivasi kerjanya

Prinsip mengakui andil bawahan

Pemimpin mengakui bahwa bahawan (pegawai) mempunyai andil didalam usaha pencapaian tujuan. Dengan pengakuan tersebut, pegawai akan lebih mudah dimotivasi kerjanya.

Prinsip pendelegasian wewenang

Pemimpin yang memberikan otoritas atau wewenang kepada pegawai bawahan untuk sewaktu waktu dapat mengambil keputusan terhadap pekerjaan yang dilakukannya, akan membuat pegawai yang bersangkutan menjadi termotivasi untuk mencapai tujuan yang diharapkan oleh pemimpin.

Prinsip memberi perhatian

Pemimpin memberikan perhatian terhadap apa yang diinginkan pegawai.

\section{Kinerja}

Pengertian kinerja yaitu suatu hasil kerja yang dihasilkan oleh seorang karyawan diartikan untuk mencapai tujuan yang diharapkan. Menurut Tika (2006) kinerja sebagai hasil-hasil fungsi pekerjaan/kegiatan seseorang atau kelompok dalam suatu organisasi yang dipengaruhi oleh berbagai faktor untuk mencapai tujuan organisasi dalam periode waktu tertentu. Menurut Rivai (2006) pengertian kinerja adalah kesediaan seseorang atau kelompok orang untuk melakukan sesuatu kegiatan dan menyempurnakannya sesuai dengan tanggung jawab dengan hasil seperti yang diharapkan. Menurut Alex (2001), terdapat berbagai faktor kinerja karyawan, antara lain:
1) Jumlah dan komposisi kompensasi yang diberikan
2) Penempatan kerja yang tepat
3) Pelatihan dan promosi

dari
4) Rasa aman di masa depan (dengan adanya pesangon dan sebagainya)

5) Hubungan dengan rekan kerja

6) Hubungan dengan pemimpin

Dari beberapa faktor di atas, maka dapat disimpulkan bahwa ada banyak faktor yang mempengaruhi kinerja karyawan. Diantaranya faktor internal antara lain: kemampuan intelektualitas, disiplin kerja, kepuasan kerja dan motivasi karyawan. Faktor eksternal meliputi: gaya kepemimpinan, lingkungan kerja, kompensasi dan sistem manajemen yang terdapat di perusahaan tersebut. Faktorfaktor tersebut hendaknya perlu diperhatikan oleh pimpinan sehingga kinerja karyawan dapat optimal.

\section{Kerangka Konseptual}

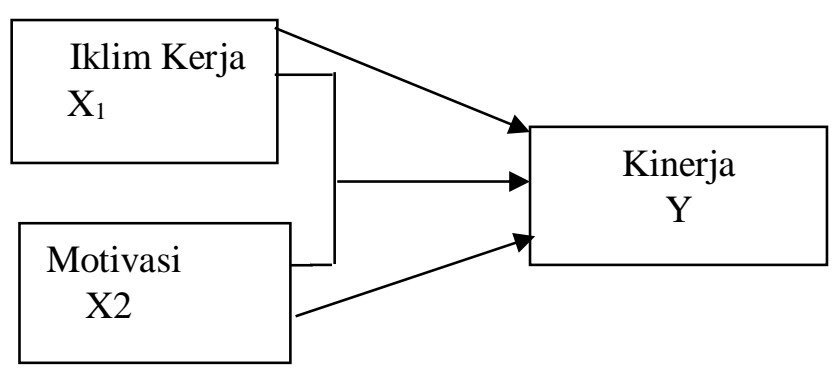

Gambar 1 : Kerangka Konseptual

\section{Hipotesis}

Berdasar pada penjelasan teoritis di atas dan kerangka pikir, maka hipotesis yang dapat diajukan adalah seperti di bawah ini :

H 1 : Terdapat pengaruh positif iklim kerja terhadap kinerjaUKMbinaan Bank Sumut Cabang Kampung Baru Medan

$\mathrm{H} 2$ : Terdapat pengaruh positifmotivasi terhadap kinerja UKM binaan Bank Sumut Cabang Kampung Baru Medan

H3: Terdapat pengaruh positif iklim kerja dan motivasi terhadap kinerja UKM binaan Bank Sumut Cabang Kampung Baru Medan

\section{METODE PENELITIAN}




\section{SULTANIST: Jurnal Manajemen dan Keuangan, Vol 9 (1), Juni 2021}

Jenis penelitian ini adalah asosiatif, yang bertujuan untuk melihat apakah terdapat pengaruh iklim kerja dan motivasi terhadap kinerja UKM binaan Bank Sumut Cabang Kampung Baru. Menurut Sugiyono (2003), bahwa sifat penelitian asosiatif pada dasarnya ingin menguji kebenaran suatu hipotesis yang dilaksanakan melalui pengumpulan data di lapangan. Penelitian inidilakukan diBank Sumut Cabang Kampung Baru Cabang Medan Jalan Bigjend Katamso no.717 B Medan. Populasi dalam penelitian ini adalah usaha mikro yang termasuk dalam kelompok SS2(Sumut Sejahtera 2) yang merupakan binaan Bank Sumut Cabang Kampung Baru Medan dengan total jumlah 77 UKM (Bank Sumut, 2014).Metode penarikan sampel dalam penelitian ini adalah berdasarkan rumus Slovin. Adapun alasan pegambilan sampel karena di Bank Sumut Cabang Kampung Baru tersebut jumlah UKM nya paling banyak dan bervariasi jenis usahanya. Pada penelitian ini jumlah sampel dibulatkan menjadi 53 orangUKM Binaan Bank Sumut Cabang Kampung Baru Medan.

\section{HASIL DAN PEMBAHASAN}

\section{Uji Validitas dan Realibilitas}

Uji validitas pada penelitian ini melakukan dengan menghitung korelasi product moment pearson ( $r$ )atau dengan melihat nilai corrected item-total correlation pada Program SPSS versi 22.0. Dikatakan valid apabila nilai $r$ hitungdiatas $r$ tabel. Jika $r$ hitung berada dibawah $r$ tabel , maka item pertanyaan tersebut harus dibuang dan tidak lagi diikutsertakan dalam uji-uji selanjutnya.Hasil uji validitas baik untuk variabel iklim kerja,.motivasi, dan kinerja yang sudah valid dan dapat digunakan ujiuji selanjutnya dapat dilihat sebagai berikut:

\begin{tabular}{|l|l|l|}
\hline \multicolumn{2}{|c|}{ Iklim Kerja } \\
\hline & $\begin{array}{l}\text { Scale Mean } \\
\text { if Item } \\
\text { Deleted }\end{array}$ & $\begin{array}{l}\text { Corrected } \\
\text { Item-Total } \\
\text { Correlation }\end{array}$ \\
\hline IK1 & 24,3962 &, 748 \\
IK2 & 24,1887 &, 757
\end{tabular}

\begin{tabular}{|l|l|l|} 
IIK3 & 24,3396 &, 573 \\
IIK4 & 24,2642 &, 481 \\
IK5 & 24,3396 &, 639 \\
IK6 & 23,7358 &, 645 \\
IK6 & 23,9811 &, 339 \\
\hline
\end{tabular}

Sumber: Data diolah (2019)

Uji validitas dilakukan untuk semua item pernyataan variabel Iklim Kerja menunjukkan bahwa nilai koefisien korelasi IK 1 - IK 7yang disajikan pada kolom $\mathrm{r}_{\text {hitung }}$ (corrected item- total correlation) diatasi $\mathrm{r}_{\text {tabel }}$ yaitu 0,3 sehingga dapat dikatakan bahwa item pernyataan variabel Iklim Kerja tersebut valid dan dapat digunakan untuk uji-uji selanjutnya.

\begin{tabular}{|l|l|l|}
\hline \multicolumn{2}{|c|}{ Motivasi } \\
\hline & $\begin{array}{l}\text { Scale Mean } \\
\text { if Item Deleted }\end{array}$ & $\begin{array}{l}\text { Corrected } \\
\text { Item-Total } \\
\text { Correlation }\end{array}$ \\
\hline M1 & 15.5849 & .734 \\
M2 & 15.4151 & .784 \\
M3 & 15.5660 & .600 \\
M4 & 15.4906 & .522 \\
M5 & 15.5283 & .591 \\
& & \\
\hline
\end{tabular}

Sumber: Data diolah (2019)

Uji validitas dilakukan untuk semua item pernyataan variabel Motivasi menunjukkan bahwa nilai koefisien korelasi M 1 - M5 yang disajikan pada kolom $\mathrm{r}_{\text {hitung }}$ (corrected item- total correlation) diatasr $\mathrm{r}_{\text {tabel }}$ yaitu 0,3sehingga dapat dikatakan bahwa item pernyataan variabel Motivasitersebut valid dan dapat digunakan untuk uji-uji selanjutnya.

\section{Kinerja}

\begin{tabular}{|l|l|l|}
\hline & $\begin{array}{l}\text { Scale Mean } \\
\text { if Item Deleted }\end{array}$ & $\begin{array}{l}\text { Corrected } \\
\text { tem-Total } \\
\text { Correlation }\end{array}$ \\
\hline K1 & 20.1132 & .743 \\
K2 & 19.9434 & .781 \\
K3 & 20.0943 & .609 \\
K4 & 20.0189 & .504
\end{tabular}

Copyright (C) 2021, SULTANIST: Jurnal Manajemen dan Keuangan 


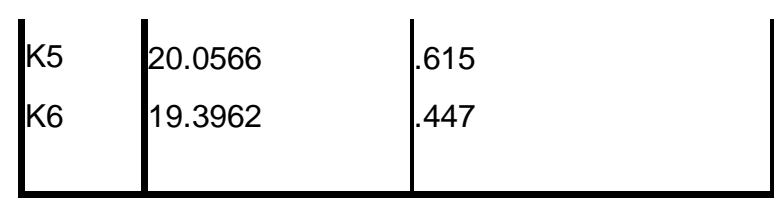

Sumber: Data diolah (2019)

Uji validitas dilakukan untuk semua item pernyataan variabel Kinerja menunjukkan bahwa nilai koefisien korelasi $\mathrm{K} 1$ - K6 yang disajikan pada kolom $\mathrm{r}_{\text {hitung }}$ (corrected item- total correlation) diatasi $\mathrm{r}_{\text {tabel }}$ yaitu 0,3sehingga dapat dikatakan bahwa item pernyataan variabel Kinerja tersebut valid dan dapat digunakan untuk uji-uji selanjutnya.

Uji Reliabilitas

\begin{tabular}{|l|l|l|l|}
\hline No & Variabel & $\begin{array}{l}\text { Nilai } \\
\text { Alpha }\end{array}$ & Kesimpulan \\
\hline 1 & $\begin{array}{l}\text { Iklim } \\
\text { Kerja } \\
\left(\mathrm{X}_{1}\right)\end{array}$ & .839 & Reliabel \\
\hline 2 & $\begin{array}{l}\text { Motivasi } \\
\left(\mathrm{X}_{2}\right)\end{array}$ & .840 & Reliabel \\
\hline 3 & $\begin{array}{l}\text { Kinerja } \\
(Y)\end{array}$ & .836 & Reliabel \\
\hline
\end{tabular}

Sumber: Data diolah (2019)

Nilai alpha masing-masing variabel besarnya diatas 0,6 sehingga instrumen yang digunakan dalam penelitian ini adalah handal (reliabel) sehingga dapat digunakan untuk uji-uji selanjutnya.

\section{Uji Asumsi Klasik}

Uji normalitas bertujuan untuk menguji apakah dalam model regresi, variabel pengganggu atau residual memiliki distribusi normal (Ghozali, 2005). Seperti diketahui bahwa uji $F$ dan uji $t$ mengasumsikan bahwa nilai residual mengikuti distribusi normal..Uji ini dapat dilakukan dengan pendekatan histogram. Hasil uji normalitas menggunakan pendekatan histogram.

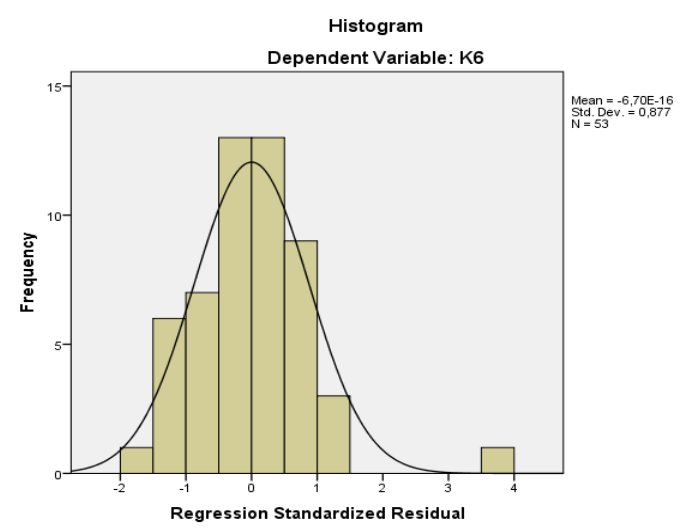

Pada grafik histogram gambar 5.1 terlihat bahwa variabel berdistribusi normal

Uji Multikolinieritas

\begin{tabular}{|l|l|l|l|}
\hline No & Variabel & Tolerance & VIF \\
\hline 1 & $\begin{array}{l}\text { Iklim Kerja } \\
\left(\mathrm{X}_{1}\right)\end{array}$ &, 709 & 1,410 \\
\hline 2 & $\begin{array}{l}\text { Motivasi } \\
\left(\mathrm{X}_{2}\right)\end{array}$ &, 435 & 2,297 \\
\hline
\end{tabular}

Sumber: Data diolah (2019)

Berdasarkan tabel dapat dilihat bahwa nilai tolerance masih berada dibawah angka 1 atau diatas 0,1 hal ini menunjukkan koefesien korelasi antara

variabel independen tidak terjadi multikolinearitas, demikian pula jika dilihat dari nilai Variance Inflaction Factor (VIF) juga masih dibawah nilai 5, maka hal berarti tidak terjadi multikolinearitas pada variabelvariabel independen

Uji Heteroskedastisitas

Pengujian ini dilakukan dalam sebuah model regresi apakah dalam sebuah model regresi terjadi ketidaksamaan varians dari residual dari suatu pengamatan ke pengamatan yang lain. Jika varians dari residual dari suatu pengamatan ke pengamatan yang lain tetap, maka disebut homokedasitas. Sebaliknya jika varians berbeda maka disebut heteroskedastisitas. Adapun model regresi yang baik adalah model regresi yang tidak terjadi 
heteroskedastisitas. Dari grafik yang disajikan dalam gambar dibawah ini, terlihat titik-titik menyebar secara acak dan tidak membentuk pola tertentu dan jelas.

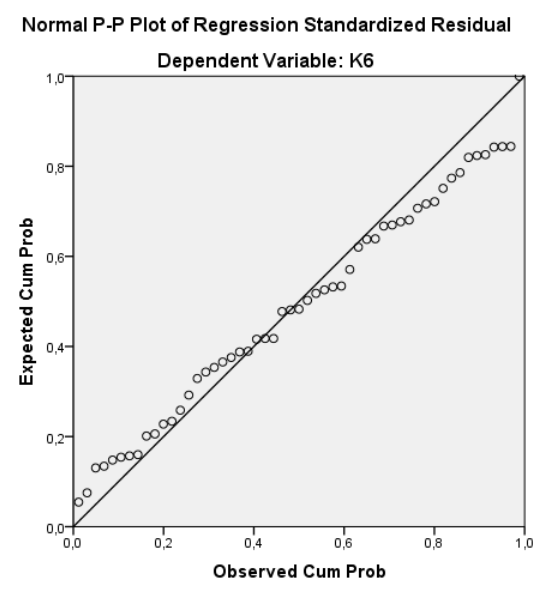

Hasil Estimasi Regresi (Model Linier)

Koefisien Determinasi

Peneliti dengan menggunakan Program SPSS, menyajikan hasil olah data untuk koefisien determinasi pada tabel dibawah ini:

\begin{tabular}{|l|l|c|l|}
\hline Model & $\mathrm{R}$ & $\begin{array}{c}\mathrm{R} \\
\text { square }\end{array}$ & $\begin{array}{l}\text { Adjusted } \\
\mathrm{R} \text { square }\end{array}$ \\
\hline 1 &, $881^{\mathrm{a}}$ &, 777 &, 710 \\
\hline
\end{tabular}

Sumber: Data diolah (2019)

Nilai R Square yang diperoleh sebesar 0,777 yang berarti bahwa 77,7 \% kinerjaUKM Binaan Bank Sumut Cabang Kampung Baru Medan dapat dijelaskan oleh faktor-faktoriklim kerja dan motivasi sedangkan sisanya yaitu sebesar 22,3\%dijelaskan oleh faktor-faktor lain seperti kompetensi, komitmen organisasi, kompensasi dan lain-lain yang tidak diteliti dalam penelitian ini sehingga lebih berpengaruh terhadap kinerja UKM Binaan Bank Sumut Cabang Kampung Baru Medan.

\section{Uji Serempak atau Simultan (Uji F)}

Uji serempak atau simultan atau uji $\mathrm{F}$ bertujuan untuk menguji hipotesis pertama yaitu mengetahui pengarul a. Dependent Var signifikan variabel-variabel independen secara bersama-sama (simultan) terhadap variabel dependen. Dibawah ini disajikan hasil Uji F dengan menggunakan SPSS.20

\begin{tabular}{|l|l|l|l|l|}
\hline Model & $\begin{array}{l}\text { Sum } \\
\text { of } \\
\text { Squares }\end{array}$ & $\begin{array}{l}\text { Mean } \\
\text { Square }\end{array}$ & F & Sig. \\
\hline Reg & 11,813 &, 984 & 11,600 &, $000^{\mathrm{b}}$ \\
\hline Res & 3,395 &, 085 & & \\
\hline Total & 15,208 & & & \\
\hline
\end{tabular}

a. Dependent Variable: K6

a. Predictors: (Constant), M5, IK4, IK7, IK3, M3, M1, IK5, M2, M4, IK6, IK1, IK2

Sumber: Data diolah (2019)

Berdasarkan data pada tabel V.28dapat dilihat bahwa $F_{\text {hitung }}=$ 11.600dengan tingkat signifikansi $0,000^{\mathrm{b}}$. Jika dibandingkan dengan $\mathrm{F}_{\text {tabel }}$ pada tingkat kepercayaan $5 \%(\alpha=0,05)$ yang besarnya hanya 3,18 maka nilai $F_{\text {hitung }}$ lebih besar dari nilai $F_{\text {tabel }} \quad\left\{F_{\text {hitung }}(11.600)<F_{\text {tabel }}(3,18)\right.$ sehingga dapat dikatakan bahwa iklim kerja dan motivasi secara simultan merupakan variabel penjelas yang signifikan terhadap kinerjaUKM Binaan Bank Sumut Cabang Kampung Baru Medan.

Uji Parsial (Uji t)

Uji parsial atau uji $t$ mempunyai tujuan untuk menguji hipotesis kedua yaitu untuk mengetahui pengaruh atau tidak secara signifikan variabel-variabel independen secara individu (parsial) terhadap variabel dependen.Dibawah ini disajikan hasil Uji t dengan menggunakan SPSS. 20

\begin{tabular}{|c|c|c|c|}
\hline \multicolumn{2}{|c|}{ Model } & $\mathrm{t}$ & Sig. \\
\hline 1 & $\begin{array}{l}\text { (Constant) } \\
\text { Iklim Kerja } \\
\text { Motivasi }\end{array}$ & $\begin{array}{l}5,312 \\
8,200 \\
, 880\end{array}$ & $\begin{array}{l}, 000 \\
, 000 \\
, 384\end{array}$ \\
\hline
\end{tabular}

a. Dependent variable: Kinerja

Sumber: Data diolah (2019) 
Untuk menentukan $\mathrm{H}_{\mathrm{o}}$ maupun $\mathrm{H}_{1}$ ditolak atau diterima maka nilai $t_{\text {hitung }}$ membandingkan dengan nilai $t_{\text {tabel }}$ pada tingkat signifikansi 5\% $(\alpha=0,05)$, dimana nilai $t_{\text {tabel }}$ pada tingkat signifikansi 5\% $(\alpha=$ 0,05 ) adalah 1,960 maka dapat diambil kesimpulan sebagai berikut :

1. Variabel Iklim Kerja

Variabel Iklim Kerja berpengaruh signifikan terhadap Kinerja UKM Binaan Bank Sumut Cabang Kampung Baru Medan.Hal ini dapat dilihat pada nilai thitung yang mencapai 8,200 diatas nilai $t_{\text {tabel }}$ sebesar 1,960

\section{Variabel Motivasi}

Variabel Motivasi tidak berpengaruh signifikan terhadap kinerja UKM Binaan Bank Sumut Cabang Kampung Baru Medan. Hal ini dapat dilihat pada nilai thitung yang mencapai 0,880 dibawah nilai $t_{\text {tabelyaitu }}$ sebesar 1,960

\section{Model Regresi (Model Linier)}

Berdasarkan hasil estimasi atau regresi, persamaan regresi dapat dirumuskan sebagai berikut:

$Y=2,626+0,755 X_{1}+0,70 X_{2}$

\section{Faktor Iklim Kerja}

Koefisien regresi menunjukkan arah positif memberikan makna adanya hubungan searah (positif) antara Iklim Kerja dengan kinerja. Jika Iklim Kerja mengalami perubahan atau peningkatan maka kinerja juga akan meningkat dan sebaliknya jika Iklim Kerja mengalami penurunan maka kinerja juga mengalami penurunan. Koefisien regresi sebesar 0,755 memberikan makna bahwa jika terjadi perubahan atau peningkatan Iklim Kerja 1 (satu) satuan maka kinerja akan meningkat sebesar 0,755 satuan.

\section{Faktor Motivasi}

Koefisien regresi menunjukkan arah positif memberikan makna adanya hubungan searah (positif) antara Motivasi dengan kinerja. Jika Motivasi mengalami perubahan atau peningkatan maka kinerja juga akan meningkat dan sebaliknya jika Motivasi mengalami penurunan maka kinerja juga mengalami penurunan. Koefisien regresi sebesar 0,70 memberikan makna bahwa jikaterjadi perubahan atau peningkatan Motivasi 1 (satu) satuan maka kinerja akan meningkat sebesar 0,70 satuan

\section{SIMPULAN DAN SARAN}

\section{Kesimpulan}

Berdasarkan pengujian yang telah dilakukan,maka dapat diperoeh kesimpulan sebagai berikut :

1. Secara parsial Iklim Kerja berpengaruh positif dan signifikan terhadap kinerja UKM Binaan Bank Sumut Cabang Kampung Baru Medan.

2. Secara parsial Motivasi tidak berpengaruh signifikan terhadap kinerja UKM Binaan Bank Sumut Cabang Kampung Baru Medan.

3. Secara simultan Iklim Kerja dan Motivasi berpengaruh positif dan signifikan terhadap kinerja UKM Binaan Bank Sumut Cabang Kampung Baru Medan.

4. Nilai R Square yang diperoleh sebesar 0,777 yang berarti bahwa $77,7 \%$ kinerja UKM Binaan Bank Sumut Cabang Kampung Baru Medan dapat dijelaskan oleh faktor-faktor Iklim Kerja dan Motivasi sedangkan sisanya yaitu sebesar 22,3\% dijelaskan oleh faktor-faktor lain seperti kompetensi, komitmen organisasi, kompensasi dan lain-lain yang tidak diteliti dalam penelitian ini.

\section{Saran}

Adapun saran-saran yang dapat diberikan dalam penelitian ini adalah :

1. Untuk penelitian berikutnya, disarankan untuk meneliti faktor-faktor lain seperti kompetensi, komitmen organisasi, kompensasi dan sebagainya.

2. Disarankan untuk meneliti pemilik UKM nya 


\section{SULTANIST: Jurnal Manajemen dan Keuangan, Vol 9 (1), Juni 2021}

3. Disarankan untuk meneliti UKM di Cabang Bank Sumut lainnya dengan sampel yang lebih banyak.

\section{DAFTAR PUSTAKA}

Alex Soemadji Nitisemito. (2001). Manajemen Personalia. Jakarta: Ghalia Indonesia.

Ayesha, I., Redjeki, F., Sudirman, A., Leonardo, A., \& Aslam, D. F. (2021). Behavior of Female Entrepreneurs in Tempe Small Micro Enterprises in Tasikmalaya Regency, West Java as Proof of Gender Equality Against AEC. Proceedings of the 2nd Annual Conference on Blended Learning, Educational Technology and Innovation (ACBLETI 2020), 560(Acbleti 2020), 124-130.

Candra, V., Silaban, P., \& Sudirman, A. (2019). Pengaruh Gaya Kepemimpinan Kepala Sekolah dan Budaya Sekolah terhadap Kinerja Guru. Harmoni Sosial: Jurnal Pendidikan IPS, 6(1), 49-60.

Chan, Syafruddin. 2003. Relationship Marketing: Inovasi Pemasaran yang Membuat. Pelanggan Bertekuk Lutut, Cetakan Kedua. Jakarta : Penerbit Gramedia.

Deluga, R. J. 1998.Leader-member exchange quality and effectiveness ratings: The role of subordinatesupervisor conscientiousness similarity. Group and Organization Management, 23, 189-216

Dessler, Gary, 2007, Manajemen Personalia,Edisi Ketiga, Jakarta: Erlangga.

Ferdinand, Augusty. 2006. Structural Equation Modelling Dalam Penelitian. Semarang : FE UNDIP.

Gibson, J.L., Ivancevich, J.M., dan Donnely Jr., J.H. 2000. Organisasi dan Manajemen: Perilaku, Struktur dan Proses. Penterjemah: Djoerban Wahid, Jakarta: Erlangga
Gordon, Judit R, 2003, A Diagnostic Approach to Organizational Behavior Boston: Allyand Bacon. Penterjemah Hadi, Soetrisno, Jakarta : Erlangga

Hadari Nawawi, 2006 Mengefektifkan Organisasi, Yogyakarta Penerbit: Gadjah Mada University Press.

Handoko, Hani ,2001 Manajemen Personalia\& Sumberdaya Manusia Edisi 2, Penerbit BPFE Yogyakarta

Hasibuan, Malayu S. P. 2008. Manajemen sumber daya manusia, Jakarta : PT. Bumi Aksara.

Lie, D., Dharma, E., \& Sudirman, A. (2021). Measurement of Teacher Performance in Pematangsiantar City Middle School Through Teacher Certification , Motivation , and Job Satisfaction. Proceedings of the 2nd Annual Conference on Blended Learning, Educational Technology and Innovation (ACBLETI 2020) Measurement, 560(Acbleti 2020), 396-401.

Luthans, Fred. 2006, Perilaku Organisasi, Edisi Pertama.Yogyakarta, Penerbit Andi, Penterjemah: Vivin Andika Yuwono dkk.

Mangkunegara, Anwar Prabu. 2005. Sumber Daya Manusia perusahaan. Bandung : Remaja Rosdakarya. . 2009. Evaluasi Kinerja Sumber Daya Manusia. Bandung: Penerbit Refika Aditama Mangkuprawira. Tb Syafri 2004, Manajemen SDM Strategik, Jakarta: PT Ghalia.

Mathis, Robert. L \& JacksonJohn.H, 2001.Manajemen Sumber Daya Manusia, Jakarta Buku Satu, Edisi Indonesia, PT Salemba Empat.

Pakpahan, G. E., Nababan, S., Simanjuntak, J., \& Sudirman, A. (2019). Pengaruh budaya organisasi, komunikasi dan kompetensi guru terhadap kinerja guru sma swasta sultan agung pematangsiantar. Jurnal Kinerja, 16(2), 131-138. 


\section{SULTANIST: Jurnal Manajemen dan Keuangan, Vol 9 (1), Juni 2021}

Purwanti, Dwi. 2012. "Peranan Seorang Guru". Diakses dari www.infodiknas.com

Rivai, Veithzal, 2006. Manajemen Sumber Daya Manusia untuk Perusahaan:dari Teori Ke Praktik. Jakarta : Penerbit PT. Raja Grafindo.

Robbins, Stephen P. Dan Judge. 2008. Perilaku Organisasi, Edisi Duabelas, penterjemah Diana Angelica dkk, Jakarta: Penerbit Salemba Empat.

Sahir, S. H., Fadhli, M., Sudirman, A.,
Hasibuan, A., Chamidah, D., Salmiah, Sherly, Revida, E., Simarmata, J., \& Purba, S. (2020). Keterampilan Manajerial Efektif. Yayasan Kita Menulis.

Siagian, Sondang. P. 2006. Sistem Informasi Manajemen. Jakarta: PT. Bumi Aksara.

Soegoto, Eddy Soeryanto. 2009. Enterpreneurship, Edisi Pertama, Jakarta: PT. Elex Media Komputindo. 